Abstracta Iranica Iranica

Revue bibliographique pour le domaine irano-aryen

Volume 32-33 | 2013

Comptes rendus des publications de 2009-2010

\title{
Farzin Vejdani. Crafting Constitutional Narratives: Iranian and Young Turk Solidarity 1907-09
}

\section{Denis Hermann}

\section{Q OpenEdition}

1 Journals

\section{Édition électronique}

URL : http://journals.openedition.org/abstractairanica/40782

DOI : 10.4000/abstractairanica.40782

ISSN : 1961-960X

Éditeur:

CNRS (UMR 7528 Mondes iraniens et indiens), Éditions de l'IFRI

\section{Édition imprimée}

Date de publication : 1 décembre 2013

ISSN : 0240-8910

\section{Référence électronique}

Denis Hermann, «Farzin Vejdani. Crafting Constitutional Narratives: Iranian and Young Turk Solidarity 1907-09 », Abstracta Iranica [En ligne], Volume 32-33 | 2013, document 298, mis en ligne le 01 juillet 2016, consulté le 03 octobre 2020. URL : http://journals.openedition.org/abstractairanica/40782 DOI : https://doi.org/10.4000/abstractairanica.40782

Ce document a été généré automatiquement le 3 octobre 2020.

Tous droits réservés 


\title{
Farzin Vejdani. Crafting Constitutional Narratives: Iranian and Young Turk Solidarity 1907-09
}

\author{
Denis Hermann
}

\section{RÉFÉRENCE}

Farzin Vejdani. «Crafting Constitutional Narratives: Iranian and Young Turk Solidarity 1907-09 ", in : Houchang E. Chehabi \& Vanessa Martin, eds., The Iranian Constitutional Revolution. Londres, I.B. Tauris, 2010, p. 319-340.

Consacrée aux relations entre pro-constitutionnalistes iraniens et ottomans, cette étude distingue à ce titre trois périodes. La première, de 1906 à l'été 1908, est marquée par l'expression par les constitutionnalistes ottomans de leur solidarité avec le mouvement constitutionnaliste iranien, dans une période où ces derniers entament un bras de fer avec le sultan. L'A. revient en particulier sur le repli en territoire iranien, et en particulier dans la province d'Azerbaïdjan, de certains militants du CUP (Committee of Union and Progress). Ces derniers y réorganisèrent leur action politique, collaborant notamment avec les militants arméniens Dashnaks et des pro-constitutionnalistes iraniens. La deuxième période traitée va de l'été 1908 à l'été 1909. L'arrivée au pouvoir des Jeunes Turcs en juillet 1908 coïncide en Iran avec la fermeture du parlement en juin 1908 et la fuite vers l'empire Ottoman d'un certain nombre de pro-constitutionnalistes iraniens qui vont utiliser ce territoire comme une base arrière pour structurer la résistance à Muhammad 'Alī Šāh. Dans cette partie Farzin Vejdani revient en détail sur les débats entre officiels ottomans quant au soutien aux réfugiés (bastis) proconstitutionnalistes iraniens dans les ambassades et consulats ottomans de Téhéran et Tabriz. La troisième et dernière période débute à l'été 1909. La résurrection du parlement en Iran est accompagnée de soubresauts dans les relations entre l'Iran et l'empire Ottoman, avec notamment l'émergence de la question des frontières et du panturquisme. La présence militaire ottomane en Iran était particulièrement ambigüe. 
Avant la restauration du parlement, le CUP put notamment envoyer des mujāhidīn ottomans combattre auprès des forces pro-constitutionnalistes d'Azerbaïdjan.

\section{AUTEURS}

\section{DENIS HERMANN}

CNRS, Mondes iranien et indien, Paris 